УДК 93/94:336.114/338.001.36/311.218

DOI: https://doi.org/10.31470/2518-7600-2020-10-84-104

SYSTEMATIZATION OF LEGISLATION OF THE RUSSIAN EMPIRE AND THE DEVELOPMENT OF FINANCIAL AND LEGAL EDUCATION IN THE DNIEPER REGION IN THE 30'S AND 40'S OF THE $19^{\text {th }}$ CENTURY

\title{
СИСТЕМАТИЗАЦІЯ ЗАКОНОДАВСТВА РОСІЙСЬКОЇ IМПЕРІЇ ТА РОЗВИТОК ФІНАНСОВО-ПРАВОВОЇ ОСВІТИ НАДДНІПРЯНЩИНИ В 30-40 РP. ХІХ СТОЛІтТЯ
}

\section{СИТЕМАТИЗАЦИЯ ЗАКОНОДАТЕЛЬСТВА РОССИЙСКОЙ ИМПЕРИИ И РАЗВИТИЕ ФИНАНСОВО-ПРАВОВОГО ОБРАЗОВАНИЯ ПРИДНЕПРОВЬЯ В 30-40 ГГ. ХІХ ВЕКА}

\section{Наталя Пасічник,}

доктор історичних наук, професор кафедри прикладної математики, статистики та економіки

pasichnyk1809@gmail.com ORCID: 0000-0002-0923-9486 ID: Q-8394-2019

Центральноукраїнський державний педагогічний університет імені Володимира Винниченка, вул. Шевченка, 1, м. Кропивницький, Україна, 25006
Natalia Pasichnyk,

Doctor of Historical Sciences, ii Professor of the Department of Applied Mathematics, Statistics and Economics

pasichnyk1809@gmail.com

ORCID:0000-0002-0923-9486

ID: Q-8394-2019

The Volodymyr Vynnychenko

Central Ukrainian State Pedagogical University Street Shevchenko, 1, Kropyvnytskyi, Ukraine, 25006 
Ренат Ріжняк,

доктор історичних наук,

професор кафедри математики rizhniak@gmail.com

ORCID: 0000-0002-1977-9048

ID: Q-3371-2019

Центральноукраїнський

державний педагогічний

університет імені Володимира

Винниченка,

вул. Шевченка, 1,

м. Кропивницький, Україна, 25006

\section{Renat Rizhniak,}

Doctor of Historical Sciences,

Professor of the Department of

Mathematics

rizhniak@gmail.com

ORCID: 0000-0002-1977-

9048

ID: Q-3371-2019

The VolodymyrVynnychenko

Central Ukrainian State

Pedagogical University

Street Shevchenko, 1,

Kropyvnytskyi, Ukraine, 25006

\section{ABSTRACT}

The article analyzes a unique act of systematization of the legislative array of the Russian Empire, that was implemented during the 30-40's of the $19^{\text {th }}$ century under the leadership of prominent statesmen M. Speranskyi and M. Baludyanskyi. The systematization of legislative acts at that time was extremely important because it provided state structures and subjects with official legal information that allowed to avoid difficulties of management and judicial proceedings; increased the effectiveness of the legal practice and case management and contributed to the improvement of laws; stimulated research in the legal field and training of professional legal experts.

The conceptual theoretical approaches and technological base of systematization of legislative acts developed by M. Speranskyi are characterized. It is determined that the systematization of the legislative array was implemented by stages, according to the developed systematization program that included: accounting of legislative acts, chronological systematization of Russian legislative acts (chronological incorporation), thematic systematization of legislation (systematic incorporation) and codification of industry legislation. The results of these stages were 
the creation of the Complete Collection of Laws of the Russian Empire, the Body of Laws, the development of comments on existing laws and educational literature for the teaching of legal disciplines in higher educational institutions of the empire.

The complete collection of laws and the Body of Laws of the Russian Empire created the basis for the development of legal science and education in general and financial and legal in particular. Based on them, the Laws on state duties and finances are being studied at the Law faculties of Kharkiv and Kyiv universities in Dnieper Ukraine. The students of the Nizhyn Law Lyceum gained financial and legal knowledge while studying the laws on state duties and finances according to the Body of Laws of the Russian Empire (Volumes IV-VIII). Instead of a general course in law, the students of the Richelieu Lyceum were studying the state economy and Russian law in 1841, also using the Complete Collection and the Body of Laws of the Russian Empire.

Keywords: financial economy, legislation, systematization of legislation, chronological incorporation, systematic incorporation, positive law, Financial Law.

Постановка проблеми. На початку XIX ст. в Російській імперії була реструктиризована система управління фінансовим господарством, яке являло собою складний об'єкт економіко-правового регулювання з розгалуженою системою. Характерною рисою управління фінансовою діяльністю було надання економічним рішенням правової форми, а регулювання фінансової діяльності в межах тогочасного імперського фінансового господарства ускладнювалося через існування значної кількості суперечливих, застарілих законів і підзаконних нормативних актів, що формували розбіжну та недостовірну інформаційну базу для юрисдикційної діяльності й унеможливлювали фінансово-правову підготовку фахівців на основі російського законодавства. Тому актуальною була проблема упорядкування й систематизації законодавчого масиву, що регламентував функціонування фінансового 
господарства й зазнав багато невдалих спроб хронологічної і систематичної інкорпорації (діяльність 10-ти попередніх Комісій для укладання узаконень - 1700 р., 1714 р., 1720 р., 1728 р., 1730 р., 1754 р., 1760 р., 1767 р., 1797 р., 1804 р.). Така масштабна систематизація законодавчої бази потребувала розробленої програми упорядкування, значних фінансових ресурсів та фахівців, здатних реалізувати організаційні програмні заходи.

Аналіз останніх досліджень і публікацій. Різноманітні аспекти проблеми систематизації законодавства в юридичній політиці Російської імперії, визначення параметрів правового регулювання тогочасних суспільних відносин в цілому та фінансово-економічних зокрема, взаємозв'язок реформування законодавчого масиву та системи університетської освіти, внесок М. Сперанського та М. Балудянського у розвиток законодавчої бази управління державним господарством виступали предметом наукових розвідок сучасних українських та зарубіжних учених - представників юридичних, економічних та історичних наук. У межах цих досліджень вважаємо за необхідне відзначити наукові пошуки К. Бєльського (Бельский, 1995), С. Голубки (Голубка, 2012: 89-95), О. Грачової (Грачева, 2015: 28-45), О. Василика (Василик, 2000), А. Васильєва (Васильев, 2004), Ф. Дударєва (Дударев, 2009: 7-10), В. Кас'янова (Касьянов, 2016: 75-77), С. Кодана (Кодан, 2007: 178-191), (Кодан, 2015: 317-326), (Кодан, 2014), В. Небрат (Небрат, 2013), Т. Латковської (Латковська, 2010: 289-291), Л. Міхневич (Міхневич, 2013: 1826), В. Томсінова (Томсинов, 2015), В. Хохуляка (Хохуляк, 2015) та ін. Проте вплив масштабної систематизації імперського законодавства на розвиток фінансово-правової освіти Наддніпрянської України, на наш погляд, потребує додаткового вивчення й узагальнення.

Мета статті - проаналізувати концептуальні підходи та поетапну реалізацію систематизації законодавчого масиву Російської імперії та визначити вплив Повного зібрання законів 
та Зводу законів на розвиток фінансово-правової освіти Наддніпрянщини.

Виклад основного матеріалу. Упорядкування законодавчої бази Російської імперії залишалося актуальною проблемою 3 початку XVIII ст. Спроби систематизації узаконень на основі галузевих кодексів першої чверті XIX ст. також виявилися безуспішними, що було пов'язано 3 відсутністю чіткої концепції робіт, нестачею фахівців, здатних виконувати відповідну діяльність, і планами кодифікації правових актів без систематизації законодавчого масиву (Кодан, 2015: 318). Тому наступна спроба систематизації імперського законодавства розпочалася з розробки теоретичної концепції, визначення загальної схеми й основних етапів систематизації законодавства та створення структури, що буде реалізовувати ці плани. Унікальний акт систематизації законодавства був здійснений на основі розробок та під керівництвом М. Сперанського та М. Балудянського - видатних державних діячів першої половини XIX ст. Їхня життєдіяльність, теоретичні ідеї та практика управлінської діяльності неодноразово виступали предметом наших наукових розвідок (Пасічник, 2018a), (Пасічник, 2018b: 186-194), (Пасічник, 2018c: 22-33), (Пасічник, 2018d: 144-150), тому в межах цієї статті ми зупинимося лише на їхніх напрацюваннях, безпосередньо пов'язаних із унікальним актом систематизації імперського законодавства.

У січні 1826 року М. Сперанський представив Миколі I дві записки - «Стислий історичний огляд комісії укладання законів», де він пояснив невдачі попередніх спроб систематизації законів за 126 років, і «Пропозиції щодо остаточного укладання законів» 3 конкретними заходами поетапної систематизації російського законодавства (Сперанский, 1826: 433-441). У квітні 1826 року замість комісії 3 укладання законів (1796-1826 рр.) було створено друге відділення імператорської канцелярії, котре прирівнювалося за значенням до міністерства. Основним іiі завданням було 
наведення порядку у діючому законодавстві через кодифікацію законодавчої бази Російської імперії з 1649 року. Керуючим другим відділенням було призначено М. Балудянського. У відділенні були сконцентровані найкращі законознавці того часу - К. Асеньєв, В. Клоков, М. Корф, О. Куніцин, М. Плісов, К. Репинський, також залучалися до практичної діяльності 3 пошуку й опису укладань студенти, серед який були майбутні відомі правознавці - Н. Крилов, К. Неволін, С. Баршев, Я. Баршев, П. Калмиков, П. Редкин та ін. (Корф, 1861).

«Structuration nova veterum legume» («Нова структура старого закону») - саме це висловлювання видатного англійського філософа, історика, державного діяча Ф. Бекона було вибрано М. Сперанським епіграфом до праці «Стислий історичний огляд комісії укладання законів». Воно відображало сутність діяльності зі створення хронологічної і тематичної інкорпорації законодавства без зміни їхньої сутності. Окремі ідеї Ф. Бекона були покладені в основу концепції укладання зводу законів, а саме: 1) виключити закони, що вийшли 3 використання; 2) виключити повторення; 3) зберегти слова закону; 4) скоротити багатослівні закони; 5) прибрати закони, що суперечать один одному; 6) під видом старих законів не повинні закрастися нові; 7) об'єднати в одному зводі закони імперські та місцеві; 8) закони охоплюють лише минуле і не визначають майбутнє (Сперанский, 1833: 102-113). Таким чином, при розробці концепції систематизації законодавчого масиву, М. Сперанський використав авторитет Ф. Бекона для того, щоб творчо переосмислити й розробити власний підхід 3 урахуванням особливостей законодавчого матеріалу, на основі яких він створювався та з урахуванням тогочасних соціальноекономічних та політичних умов в країні (Тараборин, 2015: 194-199), а умовиводи Ф. Бекона було успішно трансформовано в правила юридичної техніки (Кодан, 2007: 178-191).

За М. Сперанським систематизація законодавчого масиву: по-перше, забезпечить державні структури та підданих офіційною правовою інформацією, що сприятиме реалізації 
правових приписів та дозволить уникнути труднощів управління й судочинства; по-друге, упорядкування законів підвищить ефективність функціонування правової практики й діловодства та допомагатиме удосконаленню законів; по-третє, пожвавить проведення наукових правових досліджень i підготовку фахівців, пов'язаних у своїй діяльності з правом. (Сперанский, 1833: 87-105). 3 виданням Зводу законів «можно будет помышлять об учебных и ученых книгах и твердом образовании нашего юношества в отечественных законах» (Сперанский, 1833: 105). Актуальність зібрання й систематизації законів також зумовлена тим, що закони віддзеркалюють внутрішньодержавні процеси, зміни законодавства відображають зміни соціально-економічних i політичних процесів. Як наслідок, їхнє систематизоване збереження необхідне 3 позицій вивчення і збереження історичної спадщини держави. М. Сперанський відзначає: «история государства без познания законов, не может иметь ни ясности, ни достоверности, так как, с другой стороны законы без истории часто бывают невразумительны. Посему, чем благовременнее законы приводятся в известность, тем источники истории для современников становятся удобнее, для потомков достовернее» (Сперанский, 1833: 157).

На думку М. Сперанського, систематизацію законодавчого масиву варто здійснювати поетапно. Спочатку необхідно хронологічно систематизувати російські законодавчі акти (хронологічна інкорпорація). Результатом цього етапу буде створення Повного зібрання законів Російської імперії. На наступному етапі - здійснити тематичну систематизацію (систематична інкорпорація) законодавства на рівні Зводу законів, котрий М. Сперанський трактував як поєднання законів, існуючих з будь-якої частини, розташованих в певному порядку. Тобто М. Сперанський чітко розмежував місце і роль Зводу законів і Повного зібрання законів, розглядаючи Повне зібрання законів як законодавчу базу для відбору правового матеріалу, необхідного для укладання Зводу законів. Цей поділ 
був логічним, оскільки: аналізувати події минулого необхідно на основі законів, що діяли у той період; тексти законів потрібні для уточнення i деталізації статей Зводу законів; у законотворчій діяльності пояснювати і доповнювати закон слід 3 урахуванням попередніх трактувань. На останньому, третьому, етапі систематизації здійснювалася кодифікація галузевого законодавства, розроблялися коментарі до діючих законів та «навчальні книги» для викладання юридичних дисциплін (Сперанский, 1826: 435-436).

Підготовка Повного зібрання законів Російської імперії являла собою титанічну працю, що потребувала значної кількості кваліфікованих фахівців. Ця підготовка реалізовувалася поетапно. На першому етапі складалися реєстри узаконень (кількість законів за реєстрами - 53 239). Укладачі систематизували закони та інші нормативні правові акти Вотчинного архіву, архіву Колегії іноземних справ, Сенату, Синоду, Головного Штабу та інших державних установ СанктПетербургу й Москви. Оскільки повних реєстрів в архівах не було, потрібно було переглядати справи з узаконеннями. На другому етапі збиралися тексти законів (було опрацьовано 3596 книг, а також значна кількість справ з указами за департаментами й міністерством внутрішніх справ). Окремі узаконення звірялися з реєстрами. На третьому етапі тексти законів перевірялися укладачами окремих частин, а потім укладачами окремих томів Повного зібрання й після цього видавалися. У результаті таким чином організованої роботи виявилося, що значна кількість законодавчих актів або відмінена, або замінена/обмежена більш пізніми актами, або являла собою повторення. Відповідно табеля кількість законодавчих актів прийнятих з 29 січня 1649 року по 1 січня 1832 року було 35 993, а діюче законодавство Російської імперії складалося з 35000 актів (Сперанский, 1833: 198-200). Інформація по специфікації систематизованих законів деталізована в таблиці 1. 
Таблиия 1.

\begin{tabular}{|c|c|c|c|c|c|}
\hline Назва зібрання & $\begin{array}{l}\text { Кількість } \\
\text { статутів, } \\
\text { установ } \\
\text { указів }\end{array}$ & $\begin{array}{l}\text { Кількість } \\
\text { дарованих } \\
\text { грамот }\end{array}$ & $\begin{array}{l}\text { Кількість } \\
\text { маніфестів i } \\
\text { указів }\end{array}$ & $\begin{array}{l}\text { Кількість } \\
\text { трактатів }\end{array}$ & Всього \\
\hline $\begin{array}{ll}\text { 3ібрання перше (3 } \\
29.01 .1649 \text { п по } \\
12.12 .1825) & \end{array}$ & 819 & 241 & 29488 & 372 & 30920 \\
\hline $\begin{array}{lr}\text { Зібрання друге } & \text { (3 } \\
12.12 .1825 & \text { по } \\
01.01 .1832 & \end{array}$ & 207 & 9 & 4845 & 12 & 5073 \\
\hline Всього & 1026 & 250 & 34333 & 384 & 35993 \\
\hline
\end{tabular}

Перше видання Повного зібрання законів Російської імперії було надруковано 1 квітня 1830 року (друкування розпочато 21 травня 1828 року в спеціально створеній типографії при II-му відділенні імператорської канцеляріі), воно містило 30920 законодавчих актів, розміщених в 45 томах (40 томів - законодавчі акти, 41-й том - хронологічний вказівники, 42-й том - алфавітно-предметний вказівник, 43 і 44-й томи - штати військових, військово-морських і цивільних чинів, 45-й том - книга тарифів (Энциклопедический словарь, 1898: 349-359).

Після упорядкування законодавчого масиву, результатом якого було створення Повного зібрання законів Російської імперії та складання історичних зводів, імператорська канцелярія розпочала укладати тексти статей Зводу законів як офіційного джерела позитивного права. В основу структурування Зводу законів, як акту систематизованого нормативно-правового матеріалу, була покладена концептуальна ідея М. Сперанського - зручність використання в судочинстві та навчанні. Структурування Зводу законів здійснювалося за головними розрядами законів (з використанням сучасної термінології - за галузями законодавства), що позначали «книги», які в свою чергу ділилися на томи, а останні - на окремі зводи (Сперанский, 1833: 114). Також Звід законів розподіляв законодавство за сферами управління та економіки держави. Структура Зводу 
законів, що складався з 8 книг і 15 томів, була такою: 1) основні державні закони, установи державні, губернські, міські, уїзні, волосні та про порядок державної служби (т. I-III); 2) статути про повинності (т. IV), 3) закони казенного управління (т. VVIII); 4) закони про стани (т. IX); 5) закони цивільні та межові 3 законами про цивільне та межове судочинство (т. X); 6) статути державного благоустрою або державного господарства (т. XI-XII); 7) статути благочиння (т. XIII-XIV); 8) карні та карно-процесуальні закони (т. XV). Видання тексту «Зводу законів Російської імперії» було здійснено 1832 року. Маніфестом від 31 січня 1833 року «Про видання Зводу законів Російської імперії» відзначалося, що вітчизняні закони упорядковані, об'єднані в правильний одноманітний Звід, як того потребувало державне судочинство та порядок державного управління (ПС3, Собр.2: 68-69). Згідно маніфесту Звід законів набував юридичної сили з 1 січня 1835 року. Протягом 18321840 рр. вийшло шість Продовжень до Зводу законів. Всі томи Зводу законів перевидавалися 1842 і 1857 року, до судової реформи 1864 року він перевидавався в 15 томах. В окремому 16-му томі, виданому 1885 року, містилися судові статути.

Звід законів виступив комплексним, системоутворюючим актом, який: а) ліквідував основні недоліки загальнодержавного законодавчого масиву; б) заклав основи юридичної техніки (уніфікував термінологію, вибудував юридичні конструкції, відпрацював прийоми систематизації законодавчих актів); в) сприяв подальшому розвитку законодавства; г) виступив засобом забезпечення законності в державі; д) надав усім суб'єктам необхідну для використання нормативно-правову базу 3 хронологічної і тематичною пошуковою системами; е) створив базу для розвитку юридичної науки і освіти (Кодан, 2007: 189-190). Також Звід законів задав основні параметри навчальної програми юридичних факультетів та розподіл діючого законодавства, а, відповідно, і наукової юриспруденції на галузі (Томсинов, 2015: 16). За університетським статутом 1835 року (ПС3, Собр.2: 841- 
855), фінансова та фінансово-правова сфери починають відокремлюватися від політичної економії та вивчається разом із законами про державні повинності, а також містить складову з історії фінансів.

У цей період на юридичних факультетах університетів Наддніпрянської України - Харківського та Київського (за тимчасовим статутом університету св. Володимира 1833 року) - починають вивчатися закони про державні повинності та фінанси, викладання яких здійснюється на основі Зводу законів (а саме законів казенного управління - т. IV-VIII), історичних пояснень до Повного зібрання законів i теоретичних праць відомих на той час фінансистів. У Ніжинському юридичному ліцеї, який також вважався вищим навчальним закладом, студенти здобували фінансово-правові знання при вивченні дисципліни з назвою «закони казенного управління» (Журнал Министерства народного просвещения, 1840: 152-153). Студенти Рішельєвського ліцею з 1841 року замість загального курсу законознавства почали вивчати на фізико-математичному відділенні огляд російських законів, на камеральному відділенні - предмети «державне господарство» i «торгівля», а також огляд російських законів, на юридичному відділенні - державне господарство та російське законознавство (ПС3, Собр.2: 37-38). При викладанні законів про державні повинності та фінанси приписано було використовувати IV-VIII томи Зводу законів Російської імперії (Відділ державного архіву Чернігівської області в м. Ніжині, 1852: 6). Змістовно зазначені томи Зводу законів містили: статут про земські повинності; статут про прямі податки, мита, акцизні збори; митний статут і митні тарифи; монетний статут i гірничий; статут про казенні оброчні статті, управління казенним майном та лісовий статут. Навіть в цьому стислому переліку прослідковується правознавча та економічна складова курсу «закони про державні повинності і фінанси».

Висновки та перспективи подальших розвідок у даному напрямку. Таким чином, результатом системної 
колективної праці під керівництвом М. Сперанського та М. Балудянського була підготовка Повного зібрання законів Російської імперії і Зводу законів Російської імперії, які являли собою акти систематизації діючих законів. Формування кодифікованої законодавчої бази сприяло розвитку правознавства та виокремленню різних напрямів правознавчої науки, у тому числі й фінансово-правового. В плані продовження дослідження було б доцільно вияснити, як безпосередньо вплинула зазначена систематизація законодавства на реформування освітньої галузі Наддніпрянської України, яка проводилася у 60-х роках XIX століття у контексті Великих реформ Російської імперії.

\section{ДЖЕРЕЛА ТА ЛІТЕРАТУРА}

1. Бельский К.С. Финансовое право: наука, история, библиография. Монография. М.: Юрист, 1995. 208 с.

2. Василик О.Д. Теорія фінансів. К.: НІОС, 2000. 416 с.

3. Васильев А.В. Законодательство и правовая система дореволюционной России. СПб.: Питер, 2004. 224 с.

4. Відділ державного архіву Чернігівської області в м. Ніжині. Ф. 1359. Опис 1. Справа 100 (1852 р.). 52 арк.

5. Голубка С.М. Балудянський - реформатор і теоретик основних засад фінансово-економічної науки. Економіка України. 2012. № 7. С. 89-95

6. Грачева Е.Ю. История финансового права. История юридических наук в России. Вестник университета О.Е. Кутафина (МГЮА). 2015. № 3. С. 28-45.

7. Дудырев Ф.Ф. Систематизация законодательства и развитие юридического образования в Российской империи (1825-1840 гг.). Мунициипальное образование: инновации и эксперимент. 2009. № 6. С. 7-10.

8. Журнал Министерства народного просвещения. Часть XXVI. СПб.: Типография Императорской Академии Наук, 1840. C. $152-153$. 
9. Касьянов В.В. Влияние идей исторической школы права на кодификацию законов Российской империи. Историческая u социально-образовательная мысль. Том 8. 2016. № 4/1. C. 75-77.

10. Кодан С.В. Свод законов Российской империи. Место и роль в развитии юридической техники и систематизации законодательства в России в XIX - начале XX века. Юридическая техника. 2007. № 1. С. 178-191.

11. Кодан С.В. Совершенствование законодательства в юридической политике Российского государства в первой половине XIX века: стратегические направления и общие результаты. Юридическая техника. 2015. № 9. С. 317-326.

12. Кодан С.В., Февралёв С.А. Местное право национальных регионов в Российской империи (вторая половина XVII начало ХХ в.). Москва: Юрлитинформ, 2014. 288 с.

13. Корф М.А. Жизнь графа Сперанского. Т. 2. (Части 3, 4 и 5). СПб.: Издание императорской публичной библиотеки, 1861. $388 \mathrm{c}$.

14. Латковська Т.А. Історія та сьогодення української науки фінансового права. Правове життя сучасної України: Тези доповідей Міжнародної наук. конференції професорськовикладацького і аспірантського складу (21-22 травня 2010 року м. Одеса). Одеса: Фенікс, 2010. С. 289-291.

15. Міхневич Л.В. Рішельєвський ліцей витоки вищої юридичної освіти в Одесі. Науковий вісник Наџіонального університету біоресурсів $і$ природокористування України. 2013. Вип. 182. Ч.3. С. 18-26.

16. Небрат В.В. Еволюція теорії державних фінансів в Україні. Монографія. К.: НАН України, Ін-т екон. та прогнозув., 2013. 584 c.

17. Пасічник Н. Теоретичні ідеї та практична діяльність державних діячів Російської імперії початку XIX століття у сфері фінансового управління. Східноєвропейський історичний вісник [головний редактор В. Ільницький]. Дрогобич: Посвіт, 2018. Вип. 6. С. 22-33. 
18. Пасічник Н.О. Вклад М.А. Балудянського у розвиток фінансово-правової науки і практики управління державним господарством. Переяславський літопис: Збірник наукових статей. Переяслав-Хмельницький, 2018. Вип. 13. С. 186-194.

19. Пасічник Н.О. Вклад М.М. Сперанського у розвиток фінансово-правової науки. Наукові записки Тернопільського національного педагогічного університету імені Володимира Гнатюка. Серія: Історія. За заг. ред. проф. І.С. Зуляка. Тернопіль: Вид-во ТНПУ ім. В. Гнатюка, 2018. Вип. 1. Ч. 2. C. 144-150.

20. Пасічник Н.О. Фінансова i фінансово-правова наука i освіта в Наддніпрянській Україні в XIX - на початку XX століття [монографія]. Кропивницький: Видавництво «Код», 2018. 434 c.

21. Полное собрание законов Российской империи. Собр. 2. 1832. T. VIII. № 5947. С. 68-69.

22. Полное собрание законов Российской империи. Собр. 2. 1832. Т. Х. № 8337. С. 841-855.

23. Полное собрание законов Российской империи. Собр. 2. T. XVI. № 15010. С. 37-38.

24. Сперанский М.M. Краткое историческое обозрение комиссии составления законов. Предложения к окончательному составлению законов. Русская старина. T.XV. СПб: Печатня В.И. Головина. 1826. С. 433-441.

25. Сперанский М.М. Обозрение исторических сведений о своде законов. СПб.: Тип. II отделения собственной его императорского величества канцелярии, 1833. 206 с.

26. Тараборин Р.С. Свод законов гражданских Российской империи 1832 г.: генезис законодательной конструкции. Вопросы управления. 2015. № 2 (14). С. 194-199.

27. Томсинов В.А. Юридическое образование и юриспруденция в России во второй трети XIX века: Учебное пособие. 2-е издание. Москва: Зерцало-М, 2015. 352 с.

28. Хохуляк В.В. Наука фінансового права: проблеми становлення та розвитку: дис...д-ра. юр. наук: 12.00.07, 
12.00.01. Національний університет «Одеська юридична академія». Одеса, 2015. 545 с.

29. Энциклопедический словарь Ф.А. Брокгауза и И.А. Эфрона. Т. XXIV. С.-Пб.: Брокгауз-Эфрон, 1898. 474 с.

\section{REFERENCES}

1. Bel'skiy, K.S. (1995) Finansovoe pravo: nauka, istoriya, bibliografiya. Monografiya [The Financial law: science, history, bibliography. A Monograph]. Moskva: Yurist [in Russian].

2. Vasylyk, O.D. (2000) Teoriia finansiv [Finance Theory]. Kyiv: NIOS [in Ukrainian].

3. Vasil'yev, A.V. (2004) Zakonodatel 'stvo i pravovaya sistema dorevolyutsionnoy Rossii [Law and legal system of prerevolutionary Russia]. SPb.: Piter [in Russian].

4. Viddil derzhavnoho arkhivu Chernihivskoi oblasti $v$ m. Nizhyni [The Department of the State Archives of the Chernihiv region in Nizhyn]. F. 1359. Opys 1. Sprava 100 (1852 r.). 52 ark. [in Ukrainian].

5. Holubka, S.M. (2012) Baludianskyi reformator i teoretyk osnovnykh zasad finansovo-ekonomichnoi nauky [Baludyansky a reformer and theorist of the basic principles of financial and economic science]. Ekonomika Ukrainy - Economy of Ukraine. 7. 89-95 [in Ukrainian].

6. Gracheva, E.Yu. (2015) Istoriya finansovogo prava. Istoriya yuridicheskikh nauk v Rossii [History of Financial Law. History of the Legal Sciences in Russia]. Vestnik universiteta O.E. KutafinaThe bulletin of the O.E. Kutafin University. 3. 28.45 [in Russian].

7. Dudyrev, F.F. (2009) Sistematizatsiya zakonodatel'stva i razvitie yuridicheskogo obrazovaniya v Rossiyskoy imperii (18251840 gg.) [The systematization of legislation and the development of Law education in the Russian Empire (1825-1840)]. Munitsipal'noe obrazovanie: innovatsii i eksperiment-Municipal education: innovation and experiment. 6. 7-10 [in Russian].

8. Zhurnal Ministerstva narodnogo prosveshcheniya (1840) [Municipal education: innovation and experiment] Chast' XXVI. 
SPb.: Tipografiya Imperatorskoy Akademii Nauk. 152-153 [in Russian].

9. Kas'yanov, V.V. (2016) Vliyanie idey istoricheskoy shkoly prava na kodifikatsiyu zakonov Rossiyskoy imperii [The influence of the ideas of the historical School of Law on the codification of the laws of the Russian Empire]. Istoricheskaya i sotsial'noobrazovatel'naya mysl'-Historical and socio-educational thought. 8. 4/1. 75-77 [in Russian].

10. Kodan, S.V. (2007) Svod zakonov Rossiyskoy imperii. Mesto i rol' $v$ razvitii yuridicheskoy tekhniki i sistematizatsii zakonodatel'stva v Rossii v XIX - nachale XX veka [The set of laws of the Russian Empire. The place and role in the development of legal technology and systematization of legislation in Russia in the 19th - early 20th centuries]. Yuridicheskaya tekhnika - Legal technique. 1. 178-191 [in Russian].

11. Kodan, S.V. (2015) Sovershenstvovanie zakonodatel'stva v yuridicheskoy politike Rossiyskogo gosudarstva $\mathrm{v}$ pervuy polovine XIX veka: strategicheskie napravleniya i obshchie rezul'taty [An improvement of legislation in the legal policy of the Russian state in the first half of the 19th century: the strategic directions and overall results]. Yuridicheskaya tekhnika - Legal technique. 9. 317326 [in Russian].

12. Kodan, S.V. \& Fevralev, S.A. (2014) Mestnoe pravo natsional'nykh regionov $v$ Rossiyskoy imperii (vtoraya polovina $X V I I$ - nachalo XX v.) [The local law of national regions in the Russian Empire (second half of the 17th-early 20th centuries)]. Moskva: Yurlitinform [in Russian].

13. Korf, M.A. (1861) Zhizn' grafa Speranskogo [The life of Count Speransky]. T. 2. (Chasti 3, 4 i 5). SPb.: Izdanie imperatorskoy publichnoy biblioteki [in Russian].

14. Latkovska, T.A. (2010) Istoriia ta sohodennia ukrainskoi nauky finansovoho prava. Pravove zhyttia suchasnoi Ukrainy [History and present of Ukrainian science of Financial Law. Legal life of modern Ukraine] Proceedings from MIIM '10: Mizhnarodna nauk. konferentsia profesorsko-vykladatskoho $i$ aspirantskoho 
skladu-The conference of the teaching stuff and graduate students (pp. 289-291). Odesa: Feniks [in Ukrainian].

15. Mikhnevych, L.V. (2013) Rishelievskyi litsei vytoky vyshchoi yurydychnoi osvity v Odesi [Richelieu Lyceum as the source of higher legal education in Odessa]. Naukovyi visnyk Natsionalnoho universytetu bioresursiv $i$ pryrodokorystuvannia Ukrainy - The scientific bulletin of the National University of Life and Environmental Sciences of Ukraine. 182. 3. 18-26 [in Ukrainian]

16. Nebrat, V.V. (2013) Evoliutsiia teorii derzhavnykh finansiv $v$ Ukraini. Monohrafiia [Evolution of the theory of public finances in Ukraine. Monograph]. K.: NAN Ukrainy, In-t ekon. ta prohnozuv [in Ukrainian].

17. Pasichnyk, N. (2018c) Teoretychni idei ta praktychna diialnist derzhavnykh diiachiv Rosiiskoi imperii pochatku XIX stolittia u sferi finansovoho upravlinnia [Theoretical ideas and practical activities of statesmen of the Russian Empire in the field of financial management in the early XIX th century]. Skhidnoievropeiskyi istorychnyi visnyk - The Eastern European Historical Bulletin. 6. 22-33 [in Ukrainian].

18. Pasichnyk, N.O. (2018b) Vklad M.A. Baludianskoho u rozvytok finansovo-pravovoi nauky i praktyky upravlinnia derzhavnym hospodarstvom [The contribution of M.A. Baludyansky in the development of financial and legal science and management practices of the state economy]. Pereiaslavskyi litopys: Zbirnyk naukovykh statei - Pereyaslav Chronicle: a collection of scientific articles. 13. 186-194 [in Ukrainian].

19. Pasichnyk, N.O. (2018d) Vklad M.M. Speranskoho u rozvytok finansovo-pravovoi nauky [The contribution of M.M. Speransky in the development of financial and legal science]. Naukovi zapysky Ternopilskoho natsionalnoho pedahohichnoho universytetu imeni Volodymyra Hnatiuka. Seriia: Istoriia Scientific notes of the Ternopil Volodymyr Hnatyuk National Pedagogical University. Series: History. 1. 2. 144150 [in Ukrainian]. 
20. Pasichnyk, N. O. (2018a). Finansova i finansovo-pravova nauka i osvita $v$ Naddniprianskii Ukraini $v$ XIX-na pochatku XX stolittia (monohrafiia) [Financial and legal science and education in the Dnieper Ukraine in the nineteenth and early twentieth centuries (monograph)]. Kropyvnytskyi: Vydavnytstvo «Kod» [in Ukrainian].

21. Polnoe sobranie zakonov Rossiyskoy imperii [A complete collection of laws of the Russian Empire]. Sobr. 2. 1832. VIII. 5947. 68-69 [in Russian].

22. Polnoe sobranie zakonov Rossiyskoy imperii [A complete collection of laws of the Russian Empire]. Sobr. 2. 1832. X. 8337. 841-855 [in Russian].

23. Polnoe sobranie zakonov Rossiyskoy imperii [A complete collection of laws of the Russian Empire]. Sobr. 2. XVI. 15010. 3738 [in Russian].

24. Speranskiy, M.M. (1826) Kratkoe istoricheskoe obozrenie komissii sostavleniya zakonov. Predlozheniya k okonchatel'nomu sostavleniyu zakonov [A brief historical review of the Law Drafting Commission. The suggestions for the final drafting of laws]. Russkaya starina - Russian antiquity. XV. SPb: Pechatnya V.I. Golovina. 433-441 [in Russian].

25. Speranskiy, M.M. (1833) Obozrenie istoricheskikh svedeniy o svode zakonov [A review of historical information about the set of laws]. SPb.: Tip. II otdeleniya sobstvennoy ego imperatorskogo velichestva kantselyarii [in Russian].

26. Taraborin, R.S. (2015) Svod zakonov grazhdanskikh Rossiyskoy imperii 1832 g.: genezis zakonodatel'noy konstruktsii [The Code of Civil Laws of the Russian Empire of 1832: Genesis of the Legislative Structure]. Voprosy upravleniya - Management issues. 2 (14). 194-199 [in Russian].

27. Tomsinov, V.A. (2015) Yuridicheskoe obrazovanie $i$ yurisprudentsiya $v$ Rossii vo vtoroy treti XIX veka: Uchebnoe posobie [Legal education and jurisprudence in Russia in the second third of the 19th century: Textbook]. Moskva: Zertsalo-M [in Russian]. 
28. Khokhuliak, V.V. (2015) Nauka finansovoho prava: problemy stanovlennia ta rozvytku [The science of Financial Law: the problems of formation and development] Doctor's thesis. Odesa: Natsionalnyi universytet «Odeska yurydychna akademiia» [in Ukrainian].

29. Entsiklopedicheskiy slovar' F.A. Brokgauza i I.A. Efrona. (1898) [Encyclopedic Dictionary of F.A. Brockhaus and I.A. Efron] T. XXIV. S.-Pb.: Brokgauz-Efron [in Russian].

\section{АНОТАЦІЯ}

У статті аналізується унікальний акт систематизації законодавчого масиву Російської імперії, який реалізовувався протягом 30-40-х років ХІХ століття під керівництвом видатних державних діячів M. Сперанського та М. Балудянського. Тогочасна систематизачія законодавчих актів мала надзвичайно важливе значення, оскільки: забезпечувала державні структури та підданих офіиійною правовою інформачією, щзо дозволяло уникнути труднощів управління й судочинства; підвищувала ефективність правової практики й діловодства та сприяла удосконаленню законів; стимулювала наукові дослідження в правовій сфері та підготовку фахівиів-правознавиів.

Охарактеризовано концептуальні теоретичні підходи та технологічні основи здійснення систематизації законодавчих актів, розроблені М. Сперанським. Визначено, щзо систематизація законодавчого масиву здійснювалася поетапно, відповідно розробленої програми систематизації, котра охоплювала: облік законодавчих актів, хронологічну систематизацію російських законодавчих актів (хронологічна інкорпорація), тематичну систематизаџію законодавства (систематична інкорпорачія) та кодифікацію галузевого законодавства. Результатами реалізації цих етапів було створення Повного зібрання законів Російської імперії, Зводу законів, розробка коментарів до діючих законів та навчальної літератури для викладання юридичних дисциплін у вищих навчальних закладах імперіі. 
Повне зібрання законів і Звід законів Російської імперії створили базу для розвитку юридичної науки й освіти в иілому та фінансово-правової зокрема. На їхній основі на юридичних факультетах Харківського та Київського університетів Наддніпрянської України починають вивчатися закони про державні повинності та фінанси. Студенти Ніжинського юридичного лічеюю здобували фінансово-правові знання при вивченні законів про державні повинності та фінанси за Зводом законів Російської імперї (IV-VIII томи). Студенти Рішельєвського лічею з 1841 року замість загального курсу законознавства почали вивчати державне господарство та російське законознавство, також використовуючи Повне зібрання та Звід законів Російської імперії.

Ключові слова: фінансове господарство, законодавство, систематизачія законодавства, хронологічна інкорпорація, систематична інкорпорація, позитивне право, фінансове право.

\section{АННОТАЦИЯ}

В cтатье анализируется уникальныц акт систематизации законодательного массива Российской империи, реализовывался в течение 30-40-х годов ХІХ века под руководством выдаюшихся государственных деятелей М. Сперанского и Н. Балудянского. Тогдашняя систематизация законодательных актов имела чрезвычайно важное значение, поскольку: обеспечивала государственные структуры и подданных официальной правовой информации, что позволяло избежать трудностей управления и судопроизводства; повылила эффективность правовой практики и делопрочзводства и способствовала совершенствованию законов; стимулировала научные исследования в правовой сфере и подготовку специалистов-правоведов.

Охарактеризованы концептуальные теоретические подходы и технологические основы осуществления систематизации законодательных актов, разработанные 
M. Сперанским. Определено, что систематизация законодательного массива осуществлялась поэтапно, согласно разработанной программы систематизации, которая охватывала: учет законодательных актов, хронологическую систематизацию российских законодательных актов (хронологическая инкорпорация), тематическую систематизацию законодательства (систематическая инкорпорация) и кодификацию отраслевого законодательства. Результатами реализации этих этапов было создание Полного собрания законов Российской империи, Свода законов, разработка комментариев к действующим законам и учебной литературы для преподавания юридических дисииплин в высших учебных заведениях империи.

Полное собрание законов и Свод законов Российской империи создали базу для развития юридической науки и образования в цуелом и финансово-правовой в частности. На их основе на юридических факультетах Харьковского и Киевского университетов Приднепровской Украинь начинают изучаться законы о государственных повинностях и финансах. Студенты Нежинского юридического лицея получали финансово-правовые знания при изучении законов о государственных повинностях и финансах за Сводом законов Российской империи (IV-VIII тома). Студенты Ришельевского лищея с 1841 года взамен общего курса законоведения начали изучать государственное хозяйство и российское законоведение, также используя Полное собрание и Свод законов Российской империи.

Ключевые

законодательство, хронологическая слова: систематизация инкорпорачия, хозяйство, законодательства, систематическая инкорпорация, позитивное право, финансовое право. 